\title{
PEMBERIAN EKSTRAK TEMULAWAK DAN KUNYIT UNTUK MENINGKATKAN PRODUKTIVITAS DAN SEBAGAI IMMUNOSTIMULATOR AVIAN INFLUENZA PADA AYAM BROILER
}

\section{(The Using of Temulawak and Turmeric Extract To Enhance Productivity and as Immunostimulator of Avian Influenza In Broiler Chicken)}

Sutarto, Nuryati T

Widyaiswara,Kementerian Pendidikan dan Kebudayaan, Pusat Pengembangan dan Pemberdayaan Pendidik dan Tenaga Kependidikan Pertanian, Jalan Raya Jangari KM. 14, Desa Sukajadi, Karangtengah, Cianjur 43281,e-mail : tarttoet2008@gmail.com

Article Submitted : 19-08-2019

Article Accepted : 06-02-2020

\begin{abstract}
Broiler chickens in Indonesia have good prospects to develop. However, there are many obstacles that must be faced by broiler breeders, such as soaring prices of feed and medicine, harvest prices that tend to fluctuate, and the outbreak of bird flu that has not yet been found. The objective of the experiment was to investigate the effectiveness of treating broiler with temulawak and kunyit extracts to enhance productivity and as imunostimulator of avian influenza. Broiler were given either temulawak, kunyit or temulawak+kunyit extracts. The treatments, including a control, were arranged in a factorial design. Variables measured were production index and immune titter with haemaglutination Inhibition (HI) test at 35 days of age.Results showet that control, temulawak, kunyit and temulawak + kunyit treated chicken have production indexes of 302,$10 ; 387,11 ; 324,52$; and 354,70 , respectively. Haemaglutination Inhibition (HI) test result were all negative. It can be concluded that neither temulawak, kunyit or temulawak+ kunyit extracts is effective immunostimulator of avian influenza in broiler. Nevertheless, temulawak-treated chicken showed highest production index.
\end{abstract}

Key Words : Temulawak, Turmeic, Avian Influenza, Haemaglutination Inhibition

\section{PENDAHULUAN}

Temulawak dan kunyit merupakan salah satu dari jenis tumbuhan obat yang tumbuh di daerah dataran rendah maupun dataran tinggi, merupakan suatu anugerah dan aset negara yang tidak ternilai harganya. Oleh sebab itu, kelestarian harus tetap terjaga dan pemanfaatannya harus dilakukan seoptimal mungkin. Untuk mencapai harapan tersebut, di samping melakukan konservasi ex-situ yang selanjutnya mengarah pada usaha perbanyakan dan budidaya juga memanfaatkan tumbuhan temulawak dan kunyit seoptimal mungkin. Pemanfaatan ini tidak hanya digunakan untuk manusia saja tetapi juga dimanfaatkan untuk meningkatkan produksi ternak melalui perbaikan fisiologi produksinya.

Ayam broiler di Indonesia mempunyai prospek yang baik untuk dikembangkan, karena ternak ayam memiliki siklus produksi yang relatif singkat, sekitar 40 hari sudah dapat dipanen hasilnya. Namun demikian bukan berarti peternak ayam selalu memperoleh keuntungan, banyak kendala yang harus dihadapi oleh para peternak ayam broiler, misalnya melambungnya harga pakan dan obat-obatan, harga panen yang cenderung berfluktuasi, serta merebaknya wabah flu burung yang sampai saat ini belum ditemukan obatnya. 
Avian influenza (Flu burung) merupakan penyakit viral akut pada unggas yang disebabkan oleh virus influenza type $\mathrm{A}$ subtipe H5N1. Bulan Agustus 2003 sampai Februari 2004 terjadi wabah penyakit unggas yang menyebabkan kematian unggas sebesar $6,4 \%$ dari populasi unggas di wilayah seluruh Propinsi yang ada di Pulau Jawa, Propinsi Kalimantan Selatan, Propinsi Bali, Propinsi Kalimantan Tengah dan Propinsi Lampung. Sedangkan bulan April sampai Desember 2005 dilaporkan terjadi wabah di beberapa daerah di Jawa, Sumatera Utara, Kaltimantan Timur, Nangroe Aceh Darussalam, Riau, Kep. Riau, Sumatera Barat, Sumatera Selatan, Lampung, Bali, Sulawesi Selatan dan Sulawesi Tenggara (Direktorat Kesehatan Hewan, 2014)

Kepdirjennak No: 17/Kpts/PD.640/F/ 02.04 tanggal 4 Februari 2004 tentang Pedoman Pencegahan, Pengendalian dan Pemberantasan Penyakit Hewan Menular Influenza pada Unggas (Avian Influenza), menyatakan bahwa salah satu strategi pengendaliannya adalah melalui vaksinasi. Keberhasilan vaksinasi dilapangan sangat bervariasi tergantung banyak faktor yang mempengaruhi titer antibodi tersebut, diantaranya faktor manajemen. Adapun faktor manajemen yang dapat dilakukan peternak adalah mempersiapkan ayam sebelum vaksinasi agar mencapai tingkat kekebalan optimal dengan melalui pemberian vitamin atau obat-obatan tradisional.

Menurut Anang dan Ihsan et al. (2000), temulawak dan kunyit dapat menigkatkan kekebalan tubuh dan menyembuhkan penyakit hepatitis karena kandungan fitokimia kurkumin temulawak dan kunyit. Kandungan kurkurmin temulawak adalah desmetoksi $\neg$ kurkumin dan bisdesmetoksi kurkumin, sedangkan fitokimia kunyit adalah monodesmetoksi kurkumin dan bisdesmetoksi kurkumin. Zat fitokimia inilah yang berfungsi untuk meningkatkan nafsu makan, meningkatkan sekresi empedu, memperbaiki fungsi hati, dan memperbaiki tampilan limfosit darah. Apabila ayam sehat dan kebal dari penyakit maka nilai produktivitasnya menjadi optimal. Produktivitas ayam broiler dapat dinilai menggunakan indeks produksi, semakin tinggi nilai indeks produksi maka semakin baik cara pemelihaannya. Indeks produksi ditentukan oleh pertambahan bobot badan harian, angka kematian dan nilai konversi pakan.

Berdasarkan uraian tersebut, maka perlu kiranya diteliti manfaat temulawak dan kunyit untuk meningkatkan produktivitas dan sebagai immunostimulator avian influenza pada ayam broiler di PPPPTK Pertanian Cianjur.

\section{METODE PENELITIAN}

Penelitian dilaksanakan menggunakan ayam broiler sebanyak 200 ekor, pakan starter $240 \mathrm{~kg}$, pakan finisher $360 \mathrm{~kg}$, vitamin, antibiotik, vaksin ND, vaksin Gumboro, vaksin Flu burung (AI), tempat pakan dan tempat minum 40 set dan kandang petak 20 unit, ekstrak temulawak dan ekstrak kunyit.

Penelitian dilaksanakan dengan menggunakan metode eksperimental dan Rancangan Acak Lengkap (RAL). Perlakuan terdiri dari empat (4) kelompok, yaitu :

$\mathrm{P}_{0}$ : Sebagai kontrol

$\mathrm{P}_{1}$ : Pemberian ekstrak temulawak 0,75 g/L

P2 : Pemberian ekstrak kunyit $0,75 \mathrm{~g} / \mathrm{L}$

$\mathrm{P}_{3}$ : Pemberian ekstrak temulawak dicampur

kunyit (1:1) $0,75 \mathrm{~g} / \mathrm{L}$

Setiap unit kandang berisi 10 ekor dan diulang sebanyak 5 kali, sehingga dibutuhkan 200 ekor ayam. Pemberian ekstrak temulawak mulai umur 21 s.d. 35 hari melalui air minum.

Parameter yang diamati adalah indeks produksi (pertambahan bobot badan harian, angka kematian dan nilai konversi pakan) dan titer antibodi AI (HI test) pada ayam broiler umur 35 hari.

Pengambilan sampel darah untuk uji titer kekebalan, diambil melalui vena Brachialis sebanyak $2 \mathrm{ml}$ per ekor pada umur 35 hari (pemeriksaan hematologis), untuk satu unit diambil satu ekor (Siregar, 1988). Data indek produksi dianalisis dengan analisis variansi, dan apabila terdapat perbedaan dilanjutkan dengan uji BNJ (Steel dan Torrie, 1995). 


\section{HASIL DAN PEMBAHASAN}

\section{Produktivitas Ayam Broiler}

Rata-rata indeks produksi ayam broiler yang diberi ekstraks temulawak, kunyit, dan campuran temulawak dan kunyit melalui air minum secara rinci tertera pada Tabel 1 dan Gambar 1. Berdasarkan data Tabel 1. menunjukkan bahwa PBBH pada ayam broiler berkisar antara 65,88 - 73,55 g, FCR berkisar antara 1,90 - 2,05, daya hidup (motilitas) berkisar antara $94-100 \%$, dan indeks produksi 302,10 - 387,11. Produktivitas ayam broiler diukur berdasarkan nilai Indeks Produksi (IP). Nilai Indeks Produksi adalah perbandingan antara pertambahan bobot badan harian (g) dikalikan daya hidup (100\% persentase mortalitas) dibagi konversi pakan (FCR) dikalikan sepuluh (Chapmann, 1988). Nilai Indeks Produksi (IP) hasil penelitian ini menunjukkan perbedaan sangat nyata $(\mathrm{P}<$ 0,01) yang berarti pemberian ekstrak temulawak dan kunyit memberikan pengaruh produktivitas sama dengan kontrol atau pemberian vitamin dan antibiotika, dengan kata lain bahwa temulawak dan kunyit dapat digunakan untuk mengganti antibiotika dan vitamin pada pemeliharaan ayam broiler mulai umur 21 hari sampai dengan umur 35 hari.

Tabel 1. Perbedaan Pertambahan Bobot Badan Harian (PBBH), Feed Convertion Ratio (FCR), Mortalitas (\%), Motilitas dan Indeks Produksi (IP) setelah pemberian ekstrak temulawak dan kunyit

\begin{tabular}{lccccc}
\hline \multicolumn{1}{c}{ Perlakuan } & $\begin{array}{c}\text { PBBH } \\
\text { Umur } 21-35 \text { hari }(\mathrm{g})\end{array}$ & FCR & $\begin{array}{c}\text { Mortalitas } \\
(\%)\end{array}$ & $\begin{array}{c}\text { Motilitas } \\
(\%)\end{array}$ & IP \\
\cline { 2 - 6 } & 1 & 2 & 3 & 4 & 5 \\
\hline $\mathrm{P}_{0}$ (Kontrol) & 65,88 & 2,05 & 6 & 94 & $302,10^{\mathrm{a}}$ \\
$\mathrm{P}_{1}$ (Temulawak) & 73,55 & 1,90 & 0 & 100 & $387,11^{\mathrm{b}}$ \\
$\mathrm{P}_{2}$ (Kunyit) & 65,23 & 2,01 & 0 & 100 & $324,52^{\mathrm{c}}$ \\
$\mathrm{P}_{3}$ (Campuran) & 69,52 & 1,96 & 0 & 100 & $354,70^{\mathrm{d}}$ \\
\hline
\end{tabular}

Keterangan : Angka rata-rata yang diikuti huruf kecil yang tidak sama berbeda sangat nyata berdasarkan Uji Beda Nyata Terkecil pada taraf Nyata $1 \%$.

Hasil Indeks Produksi pada penelitian ini menunjukkan perbedaan sangat nyata $(\mathrm{P}<$ 0,01), $\mathrm{P}_{0}$ kontrol indeks produksi sebesar 302,10; $\mathrm{P}_{1}$ perlakuan temulawak 387,$11 ; \mathrm{P}_{2}$ perlakuan kunyit 324,52 dan $\mathrm{P}_{3}$ perlakuan campuran temulawak dan kunyit sebesar 354,70. Hal ini diduga pemberian temulawak dan kunyit mampu membunuh kuman patogen Escherichia coli (E. coli) dalam saluran pencernaan (Hadi, 1985) sehingga kuman non patogen tumbuh menjadi optimal, karena kandungan kurkuminoid dan minyak atsiri bersifat membunuh kuman $E$. coli dan kuman patogen lain dalam usus. Sedangkan Sufiriyanto (1998) menyatakan bahwa pemberian probiotik (Lactobacillus sp) dapat membunuh kuman E. coli sebesar $80 \%$ pada ayam broiler sehingga dapat meningkatkan bobot badan (pada umur 6 minggu dari kontrol $1.723 \mathrm{~g}$ menjadi $1.868 \mathrm{~g}$ ), menurunkan konversi pakan, meningkatkan protein efisiensi dan meningkatkan indeks produksi dari 229 menjadi 290. 


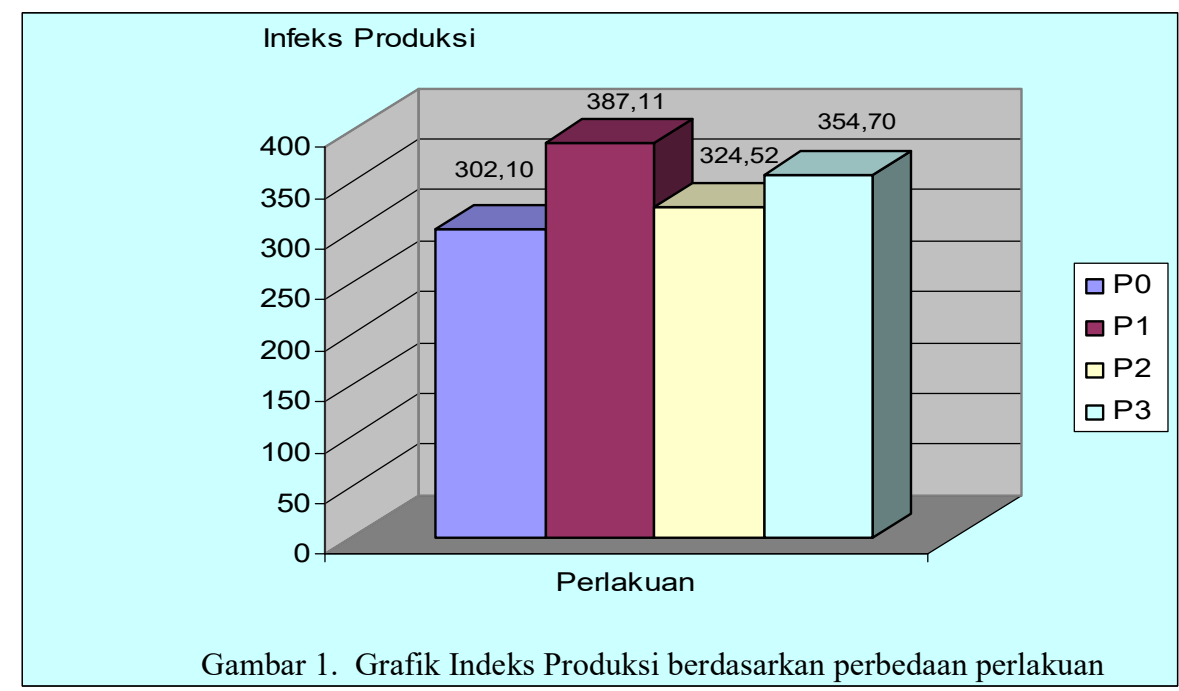

Pada penelitian ini, pemberian temulawak dosis $0,75 \mathrm{~g}$ per liter memberikan IP sebesar 387,11 dan hasil ini dikategorikan berhasil sangat baik sesuai dengan Chapmann (1988) yang menyatakan bahwa IP merupakan indikator pemeliharaan ayam broiler (kategori kurang baik bila IP dibawah 200, kategori baik bila IP 200-250, dan kategori baik sekali bila IP 250-300, serta sangat baik sekali bila IP di atas 300). Fadilah dan Polana (2004) menyatakan bahwa IP ayam broiler dikatakan baik apabila mempunyai nilai diatas 200, semakin tinggi nilai indeks produksi menunjukkan manajemen pemeliharaannya semakin baik.

Pemberian temulawak mempengaruhi bobot badan. Hasil penelitian ini memperlihatkan bahwa dengan perlakuan pemberian temulawak, bobot badan pada umur 35 hari mencapai $1.826,45 \mathrm{~g}$. Hal ini lebih baik dibandingkan dengan standard North dan Bell (1990) yang menyatakan ayam umur 5 minggu bobot badan $1.460 \mathrm{~g}$ dan umur 6 minggu mencapai bobot badan $1.890 \mathrm{~g}$, sedangkan Pauzenga (1990) mengatakan bahwa bobot badan $1.800-2.000 \mathrm{~g}$ dicapai pada ayam broiler umur 40 - 42 hari. Secara umum pertumbuhan ayam broiler akan berkembang sesuai dengan perkembangan kemajuan teknologi pakan dan genetik sehingga dari waktu ke waktu hasil pencapaian bobot badan akan berubah sesuai dengan kualitas, kondisi dan situasi setempat.

Hasil perhitungan konversi pakan pada penelitian menunjukkan perbedaan yaitu pada $\mathrm{P}_{0}$ (kontrol) sebesar 2,05, $\mathrm{P}_{1}$ sebesar 1,90; $\mathrm{P}_{2}$ sebesar 2,01 dan $\mathrm{P}_{3}$ sebesar 1,96. Angka konversi pakan semakin kecil menunjukkan hasil yang optimal, hal ini ditunjukkan pada perlakuan $\mathrm{P}_{1}$ atau perlakuan pemberian ekstrak temulawak sebesar $0,75 \mathrm{~g}$ per liter air minum. Hal ini sesuai dengan Guritno (2002) menyatakan pemberian temulawak dapat menurunkan konversi pakan sehingga secara otomatis dapat meningkatkan indeks produksi dari 290,52 menjadi 302.

Kenaikan bobot badan harian ayam broiler mulai umur 21 sampai 35 hari pada penelitian ini menunjukkan $\mathrm{P}_{0}$ (kontrol) sebesar 65,19 g, $\mathrm{P}_{1}$ (temulawak) sebesar 73,55 g, $\mathrm{P}_{2}$ (kunyit) sebesar 65,23 g dan $\mathrm{P}_{3}$ (temulawak dan kunyit) sebesar 69,52 g. Pemberian ekstrak temulawak dengan dosis sebesar $0,75 \mathrm{~g}$ per liter air minum memberikan hasil penambahan bobot badan harian yang paling optimal dibandingkan dengan perlakuan yang lain. Hal ini sesuai dengan pendapat Nataamijaya et al. (2000) bahwa pemberian kunyit pada ayam pedaging mampu meningkatkan bobot badan dari kontrol 1,37 $\mathrm{kg}$ menjadi $1,55 \mathrm{~kg}$ dengan pemberian jamu kunyit dan lempuyang perlakuan $\mathrm{K}_{5} \mathrm{~L}_{4}$ atau kunyit $0,04 \%$ dan lempuyang $0,02 \%$ diracik dalam pakan ayam broiler diberikan selama 5 
minggu. Peningkatan pertambahan bobot badan juga terjadi pada kelinci yang diberi temulawak dalam pakan pada level $0,80 \%$ (Haryanto, 2006). Kandungan kurkuminoid meningkatkan kecernaan pakan (Guritno, 2001), bersifat laktagoga (Achyas dan Rasydah, 2005) dan apabila kunyit level $0,04 \%$ dalam ransum dicampur dengan lempuyang level $0,16 \%$ dapat meningkatkan bobot badan dan menurunkan angka kematian pada ayam broiler (Nataamijaya et al., 2000). Anang dan Ihsan et al. (2000) melaporkan bahwa pemberian temulawak dan kunyit dapat meningkatkan kekebalan tubuh dan menyembuhkan penyakit hepatitis.

\section{Tingkat Kekebalan Titer HI pada Flu Burung}

Pada waktu ayam broiler berumur 21 hari dilaksanakan vaksinasi flu burung sebanyak $0,5 \mathrm{ml}$ per ekor secara injeksi subcutan, pelaksanaan pengambilan darah pada umur 35 hari. Hasil penelitian menunjukkan titer nol atau dapat dikatakan tidak adanya kekebalan berdasarkan uji Hemaglutinasi Inhibisi (HI test). Hal ini kemungkinan disebabkan oleh beberapa faktor, seperti faktor kualitas vaksin (Nurhandayani, 2004; Kawaoka et a1.,1987; Kodihalli et al., 1994), faktor strain virus (Dharmayanti et al., 2005b; Kamaludin, 2006), faktor individual ayam (Harimoto dan Kawaoka, 2001; Dharmayanti et al., 2005a; Sufiriyanto dan Indradji, 2005) dan faktor kurang pekanya metode titer HI test sehingga diperlukan uji lebih canggih. Walaupun hasil titer kekebalan $\mathrm{Al}$ nol atau negatif tetapi ayam masih mampu hidup, hal ini kemungkinan di dalam tubuh telah terjadi proses kekebalan yang bersifat seluler (Abbas et al., 1991; Rantam et al., 2004), tetapi menurut Aamir et al. (2005) bahwa titer nol sangat rentan terhadap penyakit karena ayam dapat dikatakan mampu melindungi apabila uji tentang AI minimal skor 10 sedangkan titer HI dikatakan mampu melindungi ternak ayam apabila uji titer kekebalan HI menunjukkan Geometrik HI 16 atau $2^{4}$. Titer kekebalan yang baik apabila lebih besar atau sama dengan $2^{4}$ sesuai dengan Nurhandayani (2004) yang mengatakan bahwa titer antibodi ayam setelah di vaksin dianggap berhasil apabila nilainya lebih besar atau sama dengan $2^{4}$ dan kisaran tersebut dianggap mampu melindungi ternak ayam dari serangan penyakit AI (Swayne et al., 2000; Tabbu, 2000; Setijanto dan Indradji, 2005). Pengambilan sampel darah pada tiga minggu setelah vaksinasi AI, kemungkinan hasil tersebut kurang optimal sebab untuk titer HI sebaiknya dilaksanakan satu bulan sampai dua bulan setelah vaksinasi (Hofstad et al., 1978; Kristina et al., 2004). Menurut Wood et al. (1985) waktu empat minggu ini diperlukan tubuh untuk mengadakan reaksi antigen (vaksin) dengan immunoglobulin sehingga terbentuk antibodi (Akoso, 1993).

Tingkat kekebalan atau antibodi menunjukkan kemampuan tubuh untuk proteksi terhadap agen infeksi (Alexander et al., 1986; Abbas et al., 1991). Pemeriksaan ini penting untuk penelitian lapangan pada tempat-tempat individu yang divaksinasi dan yang belum pernah divaksinasi yang dipilih secara acak (Barus, 2004). Kemampuan vaksin tidak ditentukan oleh rangsangan terjadinya antibodi serum saja, tetapi lebih dipengaruhi adanya penambahan proteksi terhadap penyakit (Bellanti, 1993). Menurui Tizzard (1983) bahwa tanggap kebal atau sensitifitas ternak dapat ditentukan dengan menemukan antibodi khusus didalam serum darah karena hewan atau ternak terpapar atau terinfeksi antigen tertentu.

Ayam broiler yang tidak divaksin AI kemungkinan besar melindungi diri dari serangan penyakit melalui mekanisme resistensi non-imunologis. Faktor-faktor yang berperan antara lain adalah lisozim, empedu dan hati, sumsum tulang, kelenjar timus dan yang utama adalah faktor interferensi dan interferon. Mekanisme pertahanan antiviral non-imunologis interferensi adalah istilah nama penghambatan replikasi virus karena adanya virus lain, karena virus lain tersebut menghasilkan interferon (Kimball, 1994). Interferon dilepaskan sel yang terinfeksi atau tertulari virus dalam beberapa jam setelah 
invasi virus maka interferon sudah terproduksi dalam jumlah yang banyak.Tizzard, 1983 mengatakan, Interferon terbentuk apabila terjadi infeksi virus yang pertama atau penyakit baru muncul dan yang terbentuk adalah interferon tipe 1 (IFN type 1) yang berfungsi menghambat proses replikasi virus dan biasanya bersamaan dengan kerja NK (Natural Killer cell) yang berfungsi melisiskan sel target infeksi (Abbas et al ., 1991).

Sistem kekebalan ayam broiler yang sakit AI, maka pada awal infeksi tubuh membentuk kekebalan melalui peningkatan sitokin sedangkan sitokin sendiri dalam tubuh macamnya banyak sekali sehingga diantara sitokin bersifat antagonis, mengakibatkan gagal pernafasan atau pneumonia akut. Pemberian temulawak dan kunyit mampu menekan sitokin, sehingga secara tidak langsung dapat menekan kejadian AI pada ayam. Menurut Nidom (2005) bahwa pemberian temulawak dapat menekan jumlah sitokin dan menghambat perkembangan virus saat virus mengalami perbanyakan diri (replication).

Kandungan zat fitokimiawi temulawak dan kunyit berfungsi memperbaiki fungsi hati atau berfungsi hepatoprotektor (Dalimartha, 2000b) dan dari tanaman obat bekerjasama memperkuat sel terhadap serangan virus pada berbagai lini mulai dari mencegah penetrasi, mencegah multiplikasi sampai dengan mencegah keluarnya virus dari dalam sel, lebih baik lagi apabila mengekstrak temulawak dan kunyit menggunakan air panas (Mursito, 2001). Selain efek menghambat replikasi virus, temulawak dapat berfungsi sebagai immunostimulator fagositosis dan meningkatkan kemampuan limfosit (Dalimartha, 2000a), hepato stimulan (Liang et al., 1985) dan hepatoprotektor mencegah kerusakan sel hati sehingga proses metabolisme dapat berlangsung lancar (Harmanto, 2007). Hal ini sesuai dengan pendapat Endrini (2007) bahwa flu burung dapat ditanggulangi dengan diberi minum tanaman obat tradisional yang bersifat antivirus dan bersifat immunostimulan serta tanaman obat yang memiliki efek konstruktif yaitu mampu memperbaiki jaringan dan kelenjar yang rusak.

\section{KESIMPULAN DAN SARAN}

\section{Kesimpulan}

Indeks Produksi optimal pada penelitian ini adalah 387,11 yang diperoleh pada pemberian ekstrak temulawak dosis $0,75 \mathrm{~g}$ per liter air minum. Pemberian kunyit dosis $0,75 \mathrm{~g}$ per liter air minum diperoleh Indeks Produksi sebesar 324,52 dan pemberian temulawak dan kunyit menghasilkan Indeks Produksi sebesar 354,70, sedangkan pada kontrol diperoleh Indeks Produksi sebesar 302,10. Titer HI pada AI tidak menunjukkan adanya perbedaan kekebalan antara perlakuan dengan kontrol.

\section{Saran}

Penggunaan ekstraks temulawak dengan dosis $0,75 \mathrm{~g} /$ liter melalui air minum mulai umur 21 hari dapat diaplikasikan di lapangan. Perlu dilakukan penelitian lebih lanjut tentang penggunaan temulawak dan kunyit sebagai pengganti vitamin dan antibiotik pada ayam broiler dan ayam petelur, uji toksisitas fitokimia sebagai pengganti antibiotik, dan uji titer antibodi menggunakan alat yang lebih canggih, seperti uji PCR (Polymerase Chain Reaction).

\section{DAFTAR PUSTAKA}

Aamir, G., N. Shaamoon, Y. Mohammed, and N. Jawad, 2005. Immunomodullatory effects of multistrain probiotics (Protexin) on broiler chicken vaccinated againts Avian Influenza Virus (H9). International Journal of Poultry Science 4(10)-.777780.

Abbas, A.K., A.H. Lichtman and Y.S.Pober, 1991. Cellular and Molecular Immunology. WB. Sounders Company. Philadelphia London Toronto Montreal Sydney Tokyo. Pp. 4-6, 38-45, 309-310.

Achyat, D.E., dan R. Rasyidah, 2005. Kunyit (Curcumae domestica Val). http//www.asiamaya.com/jamu/isi/kunyitc 
urcumaedomestica.htm. (10 September 2007).

Akoso, B.T., 1993. Manual Kesehatan Unggas. Kanisius. Yogyakarta, Hlm. 9394.

Alexander, D.J., G. Parsons and R.S. Manvell, 1986. Experimental assesment of the pathogenicity of eight avian influensa a virusses of H5 sub type for chickens Turkeys, duck and quail. Avian Pathol 15: $647-662$.

Anang, S.F.R., dan M.M. Ihsan, 2000. Temulawak dan kunyit sembuhkan hepatitis. PT. Jamu lboe. Dalam: http/www.jamuiboe.com.artikel 04php (10 September 2007).

Barus, R.A., 2004. Kronologi Wabah Avian Influenza (Al) di Indonesia. Warta Kesehatan Hewan. Media Informasi Direktorat Kesehatan Hewan. JanuariApril 2004.

Bellanti, J.A., 1993. Immunology Ill. Gajah Mada University Press. Yogyakarta.

Chapmann, J.J., 1988. Probiotics. Accidifers and Yeast Culture a Plate for Natural Additives in Pig and Poultry Production. Biotechnology in the Feed Indistries. Proceedings of Alltechs for Fourth Annual Symposium. Pp.219-223.

Dalimartha, S., 2000a. Atlas Tumbuhan Obat Indonesia. Trubus Agriwidya, Jakarta.

Dalimartha, S., 2000b. Tiga Puluh Resep Tumbuhan Obat untuk Menurunkan Kolesterol. Panebar Swadaya, Jakarta.

Dharmayanti, N.L.P.I, R. Indriani, R. Damayantt, A. Wiyono don R.M.A. Adjid, 2005a. Karakter virus avian influensa isolat Indonesia pada wabah gelombang ke duo. Jurnal Ilmu Ternak dan Veteriner 10(3) : 217-226.

Dharmayanti, N.L.P.I, R. Indriani, R. Damayanti, A. Wiyono dan R.M.A. Adjid, 2005b. Isolasi dan identifikasi wabah avian influensa pada bulan Oktober 2004-Maret 2005 In didonesia. Jurnal Biologi Indonesia. 3:341-350.

Endrini, S., 2007. Tanaman Obat Heboh Flu Burung, Herba Indonesia. Edisi 58. Yayasan Pengembang Tanaman Obat Karyasari. Jakarta.

Fadilah, R. dan A. Polana, 2004, Panduan Pengelolan Peternakan Ayam Broiler Komersial. PT Agromedia Pustaka. Depok. Jakarta.

Guritno, D., 2002. Pengaruh pemberian temulawak dan mengkudu terhadap efisiensi pakan dan protein efisinsi rasio pada ayam pedaging. [Skripsi] Fakultas Petemakan Universitas Jenderal Soedirman. Purwokerto.

Hadi, S., 1985. Maitfaat temulawak ditinjau dari segi kedokteran. Prosiding Simposium Nasional Temulawak. Lembaga Penelitian Universitas Padjadjaran. Bandung. Hlm. 139-145.

Harimoto, T., and Y. Kawaoka, 2001. Pandemic treatposed by avian influensa a viruses. Clinical Microbial Review 14: 129-149.

Harmanto, N., 2007. Avian Influenza, Mengapa Harus Takut. Dalam: Herba Indonesia. Edisi 58. Yayasan Pengembang Tanaman Obat Karyasari. Jakarta,

Haryanto, B., 2006. Pebaikan pertumbuhan dan pron. karkas melalui permberian temulawak $(C+n c r,:$ xanthoriza roxb) pada ransum. Animal Pr, Jurnal Produksi Ternak 3(8): 190-195. 
Hofstad, M.S., B. W. Calnek, C.F. Helmbolt, W.M. Raid and H. W. Yoder, 1978. Diseases Poultry. $T^{\circ}$ edition. Iowa State University Press Ames Iowa. Pp. 513-532.

Kamaludin, Z., 2006. Vaksin Al Homolog Konvensional Versus Reverse Genetic. Infovet 141.

Kawaoka, Y., A. Nestoro Wics, D.J. Alexander and R.G. Webstar, 1987. Molecular Analysis of The Haemagglutinin Genes of H5 Influenza A Viruses Origin of Virulent Turkey Strain. Virology 158: 218-227.

Kodihalli, S., V. Sivanandan, K.V. Nagaraja, D. Shaw, and D.A. Halvorson, 1994: A Type-Specivic Avian Influenza Virus Subunit Vaccine for Turkeys: Induction of Protective Immunity to Challenge Infection. Vaccine 12: 1467-1472.

Krishna, C., Isminah dan L. Wulandari, 2004. Flu Burung. Badan Penelitian dan Pengembangan Kesehatan, Departemen Kesehatan. Jakarta.

Kimball, 1. W., 1994. Biologi. Jilid 1. Penerbit Erlangga Jakarta. Hlm. 515-565.

Liang, O.B., Y. Apsorton, T. Widjaja dan S. Puspa, 1985, Beberapa Aspek Isolasi, Identifikasi dan Penggunaan Komponen komponen Curcumae xanthoriza Roxb dan Curcumae domestica Val. Prosiding Seminar Nasional Temulawak. Universitas Padjadjaran. Bandung.

Mursito, B. 2001. Sehat di Usia Lanjut Dengan Ramuan Tradisional. Panebar Swadaya. Jakarta.

Nataamijaya, A.G., S.N. Jamari, U. Kusnadi dan L. Prakarani, 2000. Pengaruh Pemberian Kunyit (Curcumae domestica Van dan Lempuyang (Zingiber aromaticum Van terhadap Bobot Badan dan Konversi Pakan pada Broiler. Prosiding Seminar Nasional Petemakan Veteriner. Pusat Penelitian dan Pengembangan Peternakan. Bogor.

Nidom, C.A., 2005. Tangerang Miniatur Indonesia. Poultry Indonesia 305. Jakarta.

North, O.M. and D.D. Bell, 1990. Commercial Chicken Production Mannual. $4^{\text {th }}$ ed. Avi. Pub. New York.

Nurhandayani, A., 2004. Avian Influenza (Fowl Plague). Swadesi I(I): 1-8.

Rantam, F.A., A.P. Rahardjo, dan A.T.S. Estoepangestie, 2004. Deteksi Dini Penyakit Avian Influenza (Al) pada Ayam Secara in Vitro dan in Vivo. Makalah Pertemuan llmiah Tahunan Perhimpunan Mikrobiologi Indonesia, 27-28 Agustus 2004. Hlm. 41. Universitas Diponegoro. Semarang.

Steel, R.G.D. and J.H. Torrie, 1980. Principles and Procedure of Statistics. $2^{\text {rd }}$ ed., Mc. Grave Hill., International Book. Co., Singapura.

Sufiriyanto, 1998. Pengaruh Pemberian Campuran Amilase, Protease dan Probiotik Melalui Air Minum Terhadap Kinerja Ayam Ras Pedaging. [Tesis]. Program Studi Sain Veteriner. Fakultas Kedokteran Hewan. Universitas Gadjah Mada. Yogyakarta

Sufriyanto dan M. Indradji, 2005. Uji Coba Lapang (field trial) Efektivitas Vaksin Avian Influenza (Flu Burung) pada Ayam Kampung di Kabupaten Banyumas. [Laporan Penelitian]. Fakultas Petemakan Unsoed (tidak dipublikasikan).

Swayne, D.E., M. Garcia, J.R Beck, N. Kinney, and D.I. Suarez, 2000. Protection against diverse higly pathogenic $\mathrm{H} 5$ avian influenza viruses in chickens immunized 
with a recombinant fowlpox vaccine containing an H5 avian influenza hemagglutinin gene insert. Vaccine 18: 1088-1095.

Tabbu, C.R., 2000. Penyakit Ayam dan Penanggulangannya. Penyakit Bakterial Mikal dan Viral. Volume 1. Penerbit Kanisius Yogyakarta Hlm. 233-245.
Tizzard, 1., 1983. Pengantar Immunologi Veteriner. Airlangga University Press. Surabaya. H1m.143-275.

Wood, J.M, Y. Kawaoka, L.A. Newberry, E. Bordwell, and R.G. Webster, 1985. Standardization of inactivated $\mathrm{H} 5 \mathrm{~N} 2$ influenza vaccine and efficacy against lethal A. Avian Diseases 29: 68-78. 